\title{
Cooperative Learning Using Jigsaw Type on Thematic Learning
}

\author{
$1^{\text {st }}$ Ratna Purwanty* \\ Departmen of Pre-School and \\ Elementary School Education \\ Universitas Musamus \\ Merauke, Indonesia \\ ratnapurwanty@unmus.ac.id \\ $4^{\text {th }}$ Rudolfus Ruma Bay \\ Departmen of Pre-School and \\ Elementary School Education \\ Universitas Musamus \\ Merauke, Indonesia \\ rbay@unmus.ac.id
}

\author{
$2^{\text {st }}$ Fredy \\ Departmen of Pre-School and \\ Elementary School Education \\ Universitas Musamus \\ Merauke, Indonesia \\ fredy_pgsd@unmus.ac.id
}

\author{
$3^{\text {st }}$ Umar Yampap \\ Departmen of Pre-School and \\ Elementary School Education \\ Universitas Musamus \\ Merauke, Indonesia \\ yampap_fkip@unmus.ac.id
}

\begin{abstract}
This paper describe learning in the 2013 curriculum using the theme "My Place of Regions" which is described as the sub-theme of "The Uniqueness of My Places of Occupation" using the cooperative learning model, the type of jigsaw. The application of the jigsaw cooperative model in learning is quite effective. This can be seen from the students' mastery of the material being studied. Students are able to answer questions given by the teacher both directly and through LKS well. Be concluded as follows. (1) The application of a jigsaw type cooperative model to the material "The Uniqueness of My Place Area" is quite effective. (2) The role of the teacher in learning using the jigsaw cooperative model is as a facilitator of learning activities, not as a center or source of all information, thus students will have the opportunity to develop in a variety of abilities and will also enhance student creativity. (3) The use of a jigsaw cooperative model is not only able to develop students 'cognitive but also able to develop students' affective domains such as cooperation, tolerance, responsibility for sharing and courage of students in expressing opinions, and other characteristics that are useful in establishing a relationship between students.
\end{abstract}

Keywords: cooperative learning, jigsaw, thematic learning

\section{INTRODUCTION}

Education plays an important and strategic role in educating the life of the nation. Quality human resources are produced through quality education as well. The aim of national education is to optimize the potential of students who believe and fear God who is characterized by noble character, broad-minded, creative, innovative, independent, healthy and responsible in realizing democratic citizens and obeying applicable rules. Various efforts are made by the government to achieve national education goals, one of which is curriculum change [1]. The curriculum is a set of lessons or educational programs that contain content, objectives, and teaching materials as well as models or methods provided as a reference for carrying out learning activities in an effort to achieve the desired expectations of education [2].
The 2013 curriculum is the current curriculum. The learning paradigm is that it is initially teacher-centered, becomes student-centered learning. The implementation of 2013 Curriculum learning in Primary schools is done through learning with an integrated approach from grade 1 to grade 6. Integrative thematic learning is an approach that combines several competencies from various subjects into specific themes. Therefore, in the 2013 curriculum that applies to primary school is no longer known as a subject but a theme. In one theme there are 6 sub-themes and one sub-theme consists of 6 lessons. Every learning has several basic competencies that are integrated into one learning according to the theme.

The theme "My Place of Regions" is one of the themes in grade 4 of primary school. In this theme, there is a sub-theme "The Uniqueness of the Area I live in". The basic competency of social science is one of the integrated competencies in the sub-theme of "The Uniqueness of the Area I live in". In these basic-competency students are asked to explain the uniqueness of the regions in Indonesia based on their geographical location.

Learning in the 2013 curriculum that uses a scientific approach will be easily achieved and supported by the appropriate learning model [3]. Cooperative learning models can be used to support the achievement of the 2013 curriculum objectives. Implementation of cooperative learning models creates active learning and student achievement [4-5]. Cooperative learning is a learning model that prioritizes student collaboration to achieve learning goals. The learning conditions of students in cooperative models are collaborative in groups. They must be able to discuss with other group members in an effort to complete the assignment given by the teacher. Cooperative learning is part of constructivist-based learning, namely learning that uses small groups where each student in his group can participate in clearly defined collective tasks. Cooperative learning is students learning in small groups that are heterogeneous in terms of gender, ethnicity and academic ability to help each other in achieving common goals [6-7]. 
Cooperative learning models can be developed following the characteristics of students and the material to be learned so that the teacher can create conducive situations and conditions so that teaching and learning activities take place following the expected goals. Johnson \& Johnson [8] mentions the main purpose of cooperative learning models is to optimize student learning as an effort to improve student achievement both individually and in groups. Cooperative learning model is a group or team learning, this model influences students' social relations from multi ethnicity, gender, and academic abilities [9-10].

Cooperative learning consists of several types, one of which is a jigsaw cooperative model. Jigsaw is one of the cooperative learning models that can support the achievement of competencies in the 2013 curriculum. Since 1978, Aronson and friends at the University of Texas and Johns Hopkins University have developed a Jigsaw type cooperative learning model [6]. Jigsaw type is cooperative learning that utilizes student learning in groups of origin and experts consisting of four to six heterogeneous people [11]. The jigsaw cooperative learning model provides many opportunities for students to express their opinions and process information obtained. The jigsaw cooperative learning model is similar to inter-group exchanges. The difference is that each student teaches something. This model is an attractive alternative if there is a learning material that can be segmented. Each student learns every part which when combined will form a unified knowledge [12-13]

The Jigsaw cooperative learning model allows students to be divided into groups of origin and expert groups. The original group is a parent group consisting of students who have different academic abilities. Expert groups are groups consisting of different members from the original group who are assigned to study and explore specific topics and complete related tasks. With the topic explained to the original group. Cooperative learning type jigsaw, students are expected to be able to exchange information about the uniqueness of the region in Indonesia based on information obtained from expert groups.

The jigsaw cooperative learning model is designed to increase students' sense of responsibility for their learning and other people's learning. Students not only learn the material provided, but they must also be ready to provide and teach the material to other group members. Thus, students are interdependent with other members and must cooperate cooperatively to study the material assigned.

According to Lie [14], the jigsaw cooperative learning model, as well as other group-based learning, has interrelated elements, including the following. (1) Positive interdependence, this positive dependence does not mean that students depend entirely on other students. If students rely on other friends without giving or becoming dependent on others, it cannot be called positive dependence. Johnson at the University of Minnesota, Shlomo Sharan at Tel Aviv University, and Robert E. Slavin at Johns Hopkins are researchers and practitioners who develop cooperative models as learning models that can improve student achievement and develop student interpersonal intelligence. In learning must create an atmosphere that encourages students to feel they need each other. This feeling of mutual need is called positive interdependence. Interdependence can be achieved through dependence on goals, tasks, materials or learning resources, roles, and gifts. (2) Individual accountability of the jigsaw type cooperative learning model requires individual accountability that measures the mastery of learning material for each group member and is given feedback about the learning achievements of its members so that they know each other who need help. Unlike traditional groups, individual accountability is often ignored so that tasks are often carried out by some members. In this model, students must be responsible for the tasks assigned to each member. (3) Face to face interaction, cooperative interaction requires all members in the study group to be able to face each other so that they can dialogue not only with the teacher but also with friends.

Such interactions allow children to be a source of learning for others. This is necessary because students often find it easier to learn from each other than from the teacher. (4) Social skills, this element requires students to be equipped with various social skills namely leadership, decision making, trust-building, communication skills and management conflict skills. Other social skills such as tolerance, courtesy to friends, criticizing ideas, daring to maintain logical thoughts, not dominating others, being independent, and various other traits that are useful in interpersonal relationships are not only assumed but deliberately taught. (5) Group processing, this process occurs when each group member evaluates the extent to which they interact effectively to achieve a common goal. Groups need to discuss cooperative and non-cooperative member behavior and make decisions about which behaviors should be changed or maintained.

\section{RESEARCH METHODS}

This classroom action research aims to find and solve classroom learning problems. The hope is to improve and improve the quality of teacher learning. The scientific approach in K 13 curriculum learning can be applied through a jigsaw type cooperative learning model.

This classroom action research aims to find and solve classroom learning problems. The hope is to improve and improve the quality of teacher learning. The scientific approach in K 13 curriculum learning can be applied through a jigsaw type cooperative learning model.

The jigsaw cooperative model has several advantages, among others: 1) allowing students to develop creativity, ability, and the ability to solve problems according to their own will; 2) the relationship between teacher and student can be balanced and allows the learning atmosphere to be very familiar so that it allows harmony; 3) motivating teachers to work more actively and creatively; 4) able to integrate various learning approaches, namely class, group, and individual approaches. Based on the advantages of the jigsaw type cooperative model it is expected that the use of a jigsaw cooperative model can increase students' interest in learning which will ultimately have an impact on achieving better student learning outcomes. Students will be more happy, interested, and active in participating in learning if the learning strategy or model used is following the subject matter. From the description above, the jigsaw type cooperative model can be used as one of the learning models to teach the material "The Uniqueness of My Place Area" in the grade 4 students of primary school. 


\section{RESULTS AND DISCUSSIONS}

Learning in the 2013 curriculum uses a scientific approach. The steps of the scientific approach include observing, asking, gathering information, trying, and communicating. The scientific approach can be combined with other learning models such as cooperative learning models.

Discussion of students in groups to achieve learning goals was emphasized in jigsaw cooperative learning. The cooperative learning model consists of various types, one of which is the jigsaw cooperative model. The jigsaw cooperative learning model is a cooperative learning model utilizing students learning in small groups of four to six in groups [11]. There are six steps of the jigsaw type cooperative model, namely: a) the teacher determines the material topic to be discussed in the group; b) students are divided into several groups. Each group consists of five students with different characteristics, this group is called the origin group; c) the teacher divides the original group into expert groups, expert groups are drawn from different origin groups to discuss the same topic; d) Students receive expert topics and read the material requested to find information related to their topic. Topics are presented in the form of text/descriptions, and each student is responsible for studying a part of the topic with a group of experts; e) then students in the expert group return to the original group to convey information or topics learned in the expert group, and f) after discussion in the original group, students are evaluated individually [6-15].

The jigsaw type cooperative learning model can be applied in teaching the themes in the 2013 Curriculum. One of the themes that can be taught through jigsaw cooperative learning is the theme "My Place of Rest". One theme consists of four sub-themes, one of which is the sub-theme of "The Uniqueness of the Area I live in." In this material, a jigsaw cooperative learning model can be used to strengthen the scientific approach which is a characteristic of learning in the 2013 Curriculum. The material "The Uniqueness of My Place of Regions" explains the various uniqueness of the regions in Indonesia. The uniqueness of each region is used as the topic of discussion in each group of experts so that through the jigsaw cooperative model information can be obtained about the uniqueness of places in Indonesia.

The implementation of jigsaw type cooperative learning in class is held on November 8, 2019. The implementation of learning includes initial activities, core activities, and closing activities. Before carrying out learning activities, the teacher first prepares the Learning Implementation Plan, learning media, and instruments needed. The learning steps listed in the lesson plan are the steps of the jigsaw type cooperative learning model. Before the implementation of learning the teacher also prepares material topics that will be discussed in learning using the jigsaw cooperative learning model.

The implementation of learning activities using the jigsaw cooperative model starts from the initial activity. The initial activity consists of checking the presence of students, giving apperception and motivation to attract students' attention, namely: a) the teacher motivates students by inviting students "Pat Spirit"; b) students and teachers ask questions about the previous material and associate with the material to be learned (apperception); c) the teacher shows a map of Merauke Regency on the powerpoint slide and students observe the map along with one of the uniqueness that is in Merauke Regency, namely Musamus; d) the teacher conveys the theme, sub-themes and learning objectives that will be achieved, the theme to be studied is "My Place of Regions" with the sub-theme "The Uniqueness of the Area I live in".

At the core activity is the practice of learning the type of jigsaw cooperative learning model on the material "The Uniqueness of the Area I live in". The complete learning steps are as follows. The first step is the teacher conveying information about the uniqueness found in the Musamus. Step two, the teacher divides the class into 3 groups, each group consists of 4 students, this group is called the original group. The origin group is determined by the teacher based on the seat arranged by the teacher. At this stage, there are still students who do not want to accept joining the group. So that the classroom atmosphere is not noisy, the teacher gives an understanding that the next stage will change again to join the expert group, so students have a variety of groups. Each student in the group gets a chest number, from numbers 1 to 4. Step three, namely the teacher asks students who have the same chest number in each group to gather into one group, this group is called the expert group.

Step four, the teacher distributes reading texts that contain information about the topic to be discussed with the expert group. Each group discusses 1 topic place in Indonesia that has its uniqueness. The fifth step is that students and expert groups discuss the topics given by the teacher which will then be delivered in the original group. At this stage, students look enthusiastic with the group discussing the topic given by the teacher. Students record information obtained from the reading text on the worksheet provided by the teacher. The note serves to help students convey the information obtained from expert groups to members of the original group. In this activity, the teacher always monitors the learning process of students in each group of experts as an evaluation material for group processes in the classroom as well as to determine the extent of student activity.

During expert group discussions, students gather in expert groups, technically students who come from different origin groups with the same chest number gather together to discuss one material topic. The material discussed by each group of experts is: (a) The uniqueness of the floating market in Banjarmasin; (b) The uniqueness of Komodo Island in East Nusa Tenggara; (c) The uniqueness of stone graves in Toraja; and (d) The unique decoration of Papuans. Based on the topics to be discussed, the expert group consisted of 4 groups and each group consisted of 3 students from different groups. In this activity, there were still some students who were confused about carrying out teacher instructions, this was because the use of the jigsaw type cooperative learning model was new for fourth-grade students, so that the teacher alternately had to go around to each group to guide students or groups who felt difficulty.

Step six, after the discussion with the expert group, the teacher asks the students to return to the original group. In the original group, students take turns explaining the topics discussed in the expert group to friends in the group, the other students respond to the explanation, the teacher observes the course of the activity. In this activity, passive students still do not want to convey the material to other friends because some students have not mastered the material 
that is their task, some students are not comfortable with the group members so they do not want to convey to their friends. The seventh step is that the teacher distributes the worksheets that must be done by the students in the original group and asks the students to discuss with the original group to answer the questions contained in the LKS. The group must also conclude the learning outcomes they have learned and acknowledge that the answers in the LKS are the results of their group work together. Step eight, presentation of the results of group work, namely representatives from each group present answers to the results of their group work with the original group in front of the class. This activity is intended to train students to dare to speak in front of the class.

Every use of the learning model allows obstacles in the process of implementation. The application of the jigsaw type cooperative learning model in the learning process experiences several obstacles including a) When students discuss, one group member tries to disturb and chat with other group members; b) the time of transfer of student groups tends to be crowded; c) when students discuss conveying information obtained from expert groups to the original group, there are still students who do not convey the information obtained from expert groups so that when working on LKS, these students work on questions they know only, not through group discussions; d) students are still shy in conveying information to their groups.

Some efforts have been made by the teacher to overcome these problems including: a) to overcome the problem so that students do not interfere and chat with other groups by means of teachers going around to check the activities or activities of students in groups and asking for difficulties in group discussions and guidance and direction to students; b) in overcoming the problem of group movement, the teacher takes turns shifting from one expert group to four expert groups so that the classroom conditions are orderly and the learning process runs smoothly; c) to overcome students who do not want to share information, the teacher guides the student to share information with group members so that group members understand what is gained from the expert group; d) to overcome so that students are not shy in informing the results of the discussion to the group, the teacher accompanies the student. Motivate students and learn to speak to convey information to their friends and give rewards to active students. After the discussion activities, students listen to the teacher giving reinforcement to the results of the discussion. Step Nine in the core activity, namely the teacher gives a question sheet to students to do individually. When working on the problem students look enthusiastic. Students who have the highest score receive a reward in the form of a star from the teacher to be placed on the student achievement box.

The last step taken in learning is the closing activity, namely the teacher invites students together to conclude the material that has been learned. The teacher gives questions to students about things that have not been understood, but no students ask. At the end of the activity, the teacher discusses with students the material they have learned and its benefits in daily life. The teacher guides students to sing the song "My Motherland" together in front of the class. he hoped, students would love the Indonesian homeland more. The teacher closes the lesson by saying hello.
Based on the description above, it can be seen that the use of the jigsaw type cooperative learning model is effective in teaching the material "The Uniqueness of the Area I live in". The use of the jigsaw type cooperative learning model is not only intended to be able to develop cognitive students but also can develop students' affective domains such as tolerance, responsibility, courage to defend opinions, not dominating others, being independent, and various other useful traits in relationships between students. The development of this attitude is not just assumed but deliberately taught to students. This is following the objectives of the 2013 curriculum, one of which is the development of the affective domain.

The application of a jigsaw type cooperative model can create success among students so that learning resources for students are not only teachers and books but also fellow students. In the jigsaw type cooperative learning model, the teacher acts more as a facilitator and motivator in learning. Such learning can create student cohesiveness both in groups and within the classroom. This is following the opinion of [11-15] which states that one of the advantages of the jigsaw type cooperative learning model is being able to integrate various learning approaches, namely class, group, and individual approaches.

One of the goals of this jigsaw is to develop teamwork, cooperative learning skills, and master knowledge in depth that is impossible to obtain if they try to learn all the material alone. This is evident when students are taught to use the jigsaw cooperative learning model students are easier to master the material being studied because through the cooperative jigsaw learning model students will share information about what they get from the results of the discussion. The type of jigsaw cooperative learning model shows concrete evidence in group learning. Although group learning, assessment is aimed at knowing students' mastery of the subject matter individually.

Overall, the application of the jigsaw type cooperative learning model in the class can be said to be quite effective. This can be seen from the students' mastery of the material being studied. Students can answer the questions given by the teacher well. These questions can be in the form of direct questions in the form of questions and answers and questions contained in student LKS. The classroom atmosphere at the time of learning also seemed quite conducive even though it experienced a few obstacles. Students also seemed enthusiastic in following the learning and doing the assignments given by the teacher.

\section{CONCLUSION}

Based on the description above can be concluded as follows. (1) The application of a jigsaw type cooperative model to the material "The Uniqueness of My Place Area" is quite effective. (2) The role of the teacher in learning using the jigsaw cooperative model is as a facilitator of learning activities, not as a center or source of all information, thus students will have the opportunity to develop in a variety of abilities and will also enhance student creativity. (3) The use of a jigsaw cooperative model is not only able to develop students 'cognitive but also able to develop students' affective domains such as cooperation, tolerance, responsibility for sharing and courage of students in expressing opinions, and other characteristics that are useful in establishing a relationship between students. 
Based on the above conclusions, the following suggestions are proposed. 1) To primary school teachers, It is expected to be able to apply the jigsaw cooperative learning model as one of the student-centered learning models. Through the right learning steps, it is a fun learning atmosphere that will be created. (2) The jigsaw cooperative learning model can be used in thematic learning with the theme "Uniqueness of the Work Area" in fourth grade students of primary school.

\section{ACKNOWLEDGMENT}

Thanks to the rector of the Universitas Musamus for publishing this work and those who have been involved in this research. It is hoped that the results of this study can contribute to improving the quality of learning in primary schools.

\section{REFERENCES}

[1] Fredy, Y. Tembang, and R. Purwanty, "Analisis Kepuasan Orangtua dan Siswa terhadap Kualitas Layanan Pendidikan Dasar," Musamus J. Prim. Educ., vol. 2, no. 1, pp. 59-66, 2019, doi: 10.35724/musjpe.v2i1.1874.

[2] Soepono, Manajemen Pengembangan Kurikulum Tingkat Satuan Pendidikan (KTSP). Jakarta: Permata Equator, 2010.

[3] Kemendikbud, Permendikbud No 103 Tentang Pembelajaran pada Pendidikan Dasar dan Menengah. Jakarta: Kementrian Pendidikan dan kebudayaan, 2014.

[4] R. R. Bay, "Peningkatan Aktivitas dan Hasil Belajar Siswa pada Mata Pelajaran Pendidikan Kewarganegaraan melalui Pembelajaran Saintifik dengan Menggunaan Media Gambar Foto di Kelas V Sekolah Dasar Negeri Boameze," Musamus J. Prim. Educ., vol. 1, no. 2, pp. 83-92, 2019.

[5] L. A. Prihandoko, Y. Tembang, D. N. Marpaung, and F. Rahman, "English language competence for tourism sector in supporting socio-economic development in Merauke: A Survey Study," IOP Conf. Ser. Earth Environ. Sci., vol. 343, no. 1, 2019, doi: 10.1088/1755-1315/343/1/012170.

[6] R. Slavin, Cooperative Learning. Bandung: Nusa Media, 2015.

[7] Y. Tembang, M. Palobo, A. K. Hermansyah, and L. A. Prihandoko, "Improving science learning outcomes in material changes in natural appearance," in IOP Conference Series: Earth and Environmental Science, 2019, vol. 343, no. 1, p. 12240.

[8] Hobri, Model-Model Pembelajaran Inovatif. Jember: Center for Society Studies (CSS), 2009.

[9] A. K. Hermansyah, A. A. Hurit, and M. N. Basaur, "Increasing the Contribution of Ethics Education through Indonesian Language Speech Culture in Elementary School," in Prosiding Seminar Nasional FKIP Universitas Mataram, 2020, vol. 1, no. 1, pp. $162-167$.

[10] D. P. Rahayu, K. W. Lieung, and Fredy, "The use of reading material based contextual approach to improve environmental concern attitude of elementary school students," IOP Conf. Ser. Earth Environ. Sci., vol. 343, no. 1, 2019, doi: 10.1088/17551315/343/1/012225.

[11] Shoimin, Model Pembelajaran Inovatif dalam Kurikulum 2013. Yogyakarta: Ar-Ruzz Media, 2014.

[12] L. Prihandoko, N. Manuhutu, M. Narahawarin, and S. Winarsih, "Designing Syllabus for Higher Education: A Reflective Study of Novice Lecturer in Merauke; Papua," in International Conference on Social Science 2019 (ICSS 2019), 2019.

[13] M. Silbermen, Strategi Pembelajaran Aktif (Active Learning). Bandung: Nusa Media, 2004.

[14] A. Lie, Cooperative Learning; Mempraktekkan Cooperative Learning di Ruang-Ruang Kelas. Jakarta: Gramedia, 2005.

[15] K. W. Lieung, D. P. Rahayu, Fredy, and A. Sulili, "The influence of scientific approach on environmental problem solving skills in elementary school students," IOP Conf. Ser. Earth Environ. Sci., vol. 343, no. 1, 2019, doi: 10.1088/1755-1315/343/1/012173.

[16] U. Yampap, D. P. Rahayu, and R. Ruma, "Application of the method of outdoor study to improve environment care attitude class IV elementary school," in IOP Conference Series: Earth and Environmental Science, 2019, vol. 343, no. 1, p. 12246. 